\title{
Lim1, an Embryonal Transcription Factor, Is Absent in Multicystic Renal Dysplasia, but Reactivated in Nephroblastomas
}

\author{
Barbara Guert| ${ }^{\mathrm{a}} \quad$ Upeka Senanayake $^{\mathrm{a}} \quad$ Elisa Nusshold $^{\mathrm{a}} \quad$ Ivo Leuschner $^{\mathrm{c}}$ \\ Sebastian Mannweiler ${ }^{a}$ Birgit Ebner ${ }^{b}$ Gerald Hoefler ${ }^{a}$ \\ a Institute of Pathology and ${ }^{b}$ Centre of Medical Research, Medical University of Graz, Graz, Austria; \\ 'Kiel Paediatric Tumor Registry, Department of Paediatric Pathology, University of Kiel, Kiel, Germany
}

\section{Key Words}

LIM1 - Multicystic renal dysplasia • Nephroblastoma •

Renal cell carcinoma • Mesenchymal-epithelial transition • PAX2

\begin{abstract}
Objective: Lim1 (Lim homeobox 1) plays an important role during rodent renal development; however, its role in human kidney development and disease is still unclear. Methods: We investigated LIM1 expression during human renal development, in dysplastic kidneys and in renal neoplasms using immunohistochemistry. RNA levels in renal carcinomas were determined by quantitative RT-PCR, and the potential roles of LIM1 in mesenchymal-epithelial transition and cell cycle were investigated in a cell culture model. $\boldsymbol{R} \boldsymbol{e}$ sults: LIM1 was detected in pretubular aggregates, S-shaped and comma-shaped bodies as well as immature glomeruli between 10 and 30 weeks of gestation. Eleven dysplastic kidneys showed no expression of LIM1. In contrast, 12 of 32 nephroblastomas showed nuclear positivity. One regressive nephroblastoma had diffuse expression of LIM1 in tubular structures, all others showed focal positivity in mesenchymal, blastemal and epithelial structures. Renal cell carcinomas revealed no expression of LIM1. Overexpression of LIM1
\end{abstract}

in a cell culture model led to an increase in KERATIN7 expression but no change in the cell cycle. Conclusion: Our study supports the concept of a causative role of LIM1 deficiency in the development of multicystic kidney. In a small subset of nephroblastomas with a more diffuse expression pattern LIM1 might also contribute to the pathogenesis of these lesions.

Copyright $\odot 2011$ S. Karger AG, Basel

\section{Introduction}

A recurring pattern in the pathogenesis of malignant tumours appears to be reactivation of embryonically active transcription factors, which are silenced during differentiation and specialisation in a variety of parenchymal tissues. A typical example is alveolar rhabdomyosarcoma with reactivation of $P A X 3$ (paired box 3) and $P A X 7$ (paired box 7) in at least $50 \%$ of all cases [1]. Another impressive example is represented by nephroblastomas. Over the past few years genes necessary for kidney development like PAX2 (paired box 2), a transcription factor involved in cell proliferation and resistance to apoptosis, and CITED1 (Cbp/p-300 interacting transactivator) have been identified to play a role in the tumourigenesis of

\section{KARGER}

Fax +41613061234 E-Mail karger@karger.ch www.karger.com

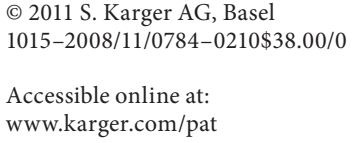

Barbara Guertl, MD

Institute of Pathology, Medical University of Graz

Auenbruggerplatz 25

AT-8036 Graz (Austria)

Tel. +43 316385 81397, E-Mail barbara.guertl-lackner@medunigraz.at 
nephroblastoma [2, 3]. Renal organogenesis in mammals is a very complex process involving many steps of mesenchymal-epithelial transition, multiplex branching of ureteric buds and differentiation into a variety of specialized epithelial tissues [4]. The urogenital system develops from the intermediate mesoderm by forming epithelial structures, called nephric ducts. During this process mesenchymal cells undergo transition into differentiated epithelial cells [5]. Lim1 is a protein of the homeobox family and possesses high homology between various mammalian species. In mice the Lim1 gene has been mapped to chromosome 11 with high homology to the human one on chromosome 17q11.2-q12 [6, 7]. During renal organogenesis Lim1 is expressed in multiple structures of the metanephros. Expression is localized in the tips of the ureteric buds, and in derivatives of the metanephric mesenchyme, the pretubular aggregates, the comma- and S-shaped bodies as well as immature glomeruli in rats and mice $[5,8]$. Renal organogenesis of Lim 1 knock-out mice was blocked at an early stage of development leading to agenesis of the kidneys accompanied by agenesis of the female and male reproductive tract $[9,10]$. Mouse embryos with complete Lim1 deficiency also lacked head structures and some of them had a kink in the spinal cord. Most of the homozygous embryos died around E10, but a few of them survived till birth, being delivered stillborn [9]. In a mouse model with tissue-specific inactivation of Lim1 in renal tissues derived from metanephric mesenchyme mice died within the first day. Inactivation of $\operatorname{Lim} 1$ in nephric duct tissue led to development of smaller kidneys, hydronephrosis and hydroureter indicating abnormal formation of the distal ureter [5]. In a mouse model with conditional knock-out of Lim1 in nephric epithelium after nephric duct formation the animals showed hypoplastic kidneys, hydronephrosis and unilateral renal agenesis (20\%). The reason of hydronephrosis seems to be vesicoureteral reflux comparable in morphology and pathogenetic mechanism with humans suffering from this disease [11]. So far, the role of LIM1 in human disease has hardly been investigated [12], only one recent study using microarray analysis indicated overexpression of LIM1 in a subset of nephroblastomas [13].

In our study we investigated the role of LIM1 during normal human kidney development, cystic renal maldevelopment and various renal neoplasms, and further explored the role of this transcription factor in a cell culture system. In addition, we evaluated the expression of PAX2 during renal development, in maldevelopment of the kidney and renal neoplasms.

Lim1 in Renal Development and Renal Neoplasms

\section{Material and Methods}

Material

Formalin-fixed and paraffin-embedded samples of archival tissue of embryonal kidneys of different gestational ages, multicystic kidneys, nephroblastomas and renal cell carcinomas were included in the study. All samples of nephroblastomas were obtained in collaboration with the Kiel Paediatric Tumour Registry, Department of Paediatric Pathology, University of Kiel, Germany.

\section{Immunohistochemistry}

Sections of approximately 3-4 $\mu \mathrm{m}$ were deparaffinated by xylene and descending alcohol solutions. After pre-treatment for 40 min in target retrieval solution pH 9 (Dako, Glostrup, Denmark) in a microwave and a cooling phase for $20 \mathrm{~min}$ at room temperature, endogenous peroxidase was blocked with $3 \% \mathrm{H}_{2} \mathrm{O}_{2}$ (Dako) for $10 \mathrm{~min}$ at room temperature. LIM1 antibodies (Santa Cruz Biotechnology Inc., Santa Cruz, Calif., USA) were used in a 1:100 dilution in antibody diluent (Dako) for $60 \mathrm{~min}$ at room temperature, followed by incubation for $30 \mathrm{~min}$ at room temperature with a secondary anti-goat antibody (Bethyl Laboratories, Montgomery, Tex., USA) diluted 1:1,000. PAX2 staining was performed with PAX2 antibodies (Abcam, Cambridge, Mass., USA) in a 1:500 dilution in antibody diluent (Dako). Dako EnVision ${ }^{\mathrm{TM}}$ Detection System (Dako) was used as detection system incubating slides for $30 \mathrm{~min}$ at room temperature followed by $10 \mathrm{~min}$ treatment with 3,3'-diaminobenzidine plus chromogen substrate (Dako). Alternatively, PAX2 staining was performed using a ready-to-use-antibody (Ventana, Tucson, Ariz., USA) in an automated Ventana staining system program $\mathrm{CC}_{1}$ standard (Ventana). Specimens were counterstained with Mayer's hemalaun.

Quantitative Real-Time-PCR

Several 3- $\mu \mathrm{m}$ sections of FFPE samples were deparaffinized and stained with Mayer's hemalaun, followed by manual dissection under the microscope as described elsewhere [14]. Total RNA from FFPE samples was isolated using the RNAeasyFFPE kit (Qiagen, Hilden, Germany). Up to $500 \mathrm{ng}$ of total RNA from FFPE samples and cell pellets were reverse transcribed into cDNA using a high-capacity cDNA reverse transcription kit (Applied Biosystems, Carlsbad, Calif., USA). Quantitative real-time-PCR (QRTPCR) was performed in triplicates with specific primers for LIM1, KERATIN7 and 18sRNA (for primer sequences, see table 1) and SYBR green as the detection fluorophore on a 7900T fast-realtime-PCR-system (Applied Biosystems) (for PCR programme, see table 2). $18 s R N A$ was used as internal control and relative gene expression levels were determined as $\Delta \Delta \mathrm{CT}$.

Statistical analysis was performed by paired t test using the Graphpad Prism software V5 (Graphpad Inc., San Diego, Calif., USA).

\section{Cell Culture Experiments}

Cells of the MRC-5 cell line (ATCC-LGC Promchem, Teddington, UK) were grown in 6-well plates to 70\% confluence. One microgram of pCMV6-AC-GFP vector (Origene, Rockville, Md., USA) containing the complete sequence of LIM1 or $1 \mu \mathrm{g}$ of the control vector was used for transfection. To obtain an appropriate MOCK vector as a negative control, the pCMV6-Ac-GFP vector containing the LIM1 coding sequence (Origene) was digested using KpnI restriction enzyme (Fermentas, St. Leon-Rot, Germany) 
Table 1. Primer sequences

\begin{tabular}{lll}
\hline Gene & Forward primer & Reverse primer \\
\hline Keratin 7 & 5'CCCGGAATGAGATTTCAGAG 3' & 5'GTAGGTGGCGATCTCGATGT 3' \\
Lim1 & 5'TCCAGGGAAGGCAAACTCTA 3' & 5'TCATGCAGGTGAAGCAGTTC 3' \\
18s RNA & 5'GTAACCCGTTGAACCCCATT 3' & 5'CCATCCAATCGGTAGTAGCG 3' \\
\hline
\end{tabular}

according to the manufacturer's instructions. Since KpnI restriction sites exist in the multiple cloning site of the vector as well as in the LIM1 open reading frame, a 208-bp fragment was excised. The fragments were separated by gel electrophoresis and the vector fragment was purified on gel. The linearized vector was religated with T4-DNA Ligase (New England Biolabs, Frankfurt am Main, Germany). The lack of the 208-bp fragment resulted in the absence of the first ATG of the LIM1 coding sequence and the introduction of a premature stop codon. Eight microlitres of Lipofectamine 2000 (Invitrogen, Carlsbad, Calif., USA), the vector and Opti-MEM ${ }^{\circledR}$ I reduced-serum medium (Invitrogen) to a final volume of $100 \mu \mathrm{l}$ were included in the transfection solution. The transfection solution was added to $1 \mathrm{ml}$ of medium already covering the cells and $1 \mathrm{ml}$ of medium $2 \mathrm{~h}$ later. After $24 \mathrm{~h}$ cells were washed with PBS and fresh medium was supplied. Thirty hours after transfection cells were harvested and deep frozen in TRIZOL (Invitrogen). Total RNA was extracted for QRT-PCR according to the manufacturer's proceedings.

For cell cycle analysis $1 \times 10^{5}$ cells were collected and resuspended in PBS, followed by centrifugation and further washing steps with $1 \%$ BSA. The cells were finally resuspended in $500 \mu \mathrm{l}$ of DNA-prep stain (Beckman Coulter, Brea, Calif., USA) and incubated for $20 \mathrm{~min}$ in the dark at room temperature. Cell cycle analysis was read on a Cytomics FC 500 (Beckman Coulter).

\section{Results}

\section{Kidney Development}

Samples of 32 regularly developed kidneys of different gestational ages from 7 weeks of gestation until the age of 2 months were included in the study. The samples were distributed in terms of gestational age as follows: 1 at 7 , 10,13 and 14 weeks each, 3 at 15 and 4 at 16 weeks, 3 at 17 weeks, 2 at 18 weeks, 1 at 19 weeks, 3 at 20 weeks, 3 at 21 weeks, 1 at 22 and 23 weeks, 2 at 28 weeks, and 1 at 30,35 and 40 weeks of gestation each. One of the samples of 28 weeks represented a 1-day-old preterm delivery. Additionally, 1 sample each from 2 days and 2 months of age were investigated. The apical tips of comma- and Sshaped bodies showed clear positivity of LIM1 between 10 and 30 weeks of gestation. Focal positivity was also detected in pretubular aggregates and some immature glomeruli. The sample of regularly developed kidney
Table 2. PCR conditions

\begin{tabular}{ll}
\hline Stage 1 & $50^{\circ} \mathrm{C} ; 2 \mathrm{~min}$ \\
\hline Stage 2 & $95^{\circ} \mathrm{C} ; 10 \mathrm{~min}$ \\
\hline Stage 3 & $95^{\circ} \mathrm{C} ; 15 \mathrm{~s}$ \\
& $60^{\circ} \mathrm{C} ; 1 \mathrm{~min}$ \\
& $45 \mathrm{cycles}$ \\
\hline Dissociation stage & $95^{\circ} \mathrm{C} ; 15 \mathrm{~s}$ \\
& $60^{\circ} \mathrm{C} ; 15 \mathrm{~s}$ \\
& $95^{\circ} \mathrm{C} ; 15 \mathrm{~s}$ \\
\hline
\end{tabular}

from 7 and 35 weeks of gestation revealed complete negativity in 2 different sets of experiments. In the kidney from 35 weeks of gestation only a very limited amount of metanephric tissue was present. The mature kidneys were entirely negative for LIM1. Samples from 10 to 35 weeks of gestation demonstrated distinct nuclear staining of PAX2 in metanephric mesenchyme, comma- and $\mathrm{S}$-shaped bodies, pretubular aggregates as well as immature glomeruli. The mature kidneys showed only focal faint nuclear positivity for PAX2 in the collecting ducts. Residual immature tubules in the sample of 35 weeks of gestation showed a distinct expression of PAX2 (fig. 1). The sample from 7 weeks of gestation was not available for evaluation of PAX2 (also see table 3).

\section{Nephroblastomas}

Thirty-two nephroblastomas were analyzed in our study, including 4 epithelial-type nephroblastomas, 2 stroma-type nephroblastomas with ectopic mesenchymal differentiation, 16 mixed nephroblastomas, 5 regressive ones, 4 blastema-type ones and 1 cystic nephroblastoma.

The cystic nephroblastoma showed mesenchymal and epithelial structures including immature glomeruloid bodies. All samples of regressive nephroblastomas contained representative vital tumour areas with different structures. All 5 showed tubular structures, 4 of them mesenchymal areas and 2 additionally skeletal muscle, 
Fig. 1. Expression of LIM1 and PAX2 during normal human kidney development. LIM1 is present in comma-shaped bodies (a, $\times 400)$, S-shaped bodies $(\mathbf{b}, \times 400)$ and pretubular aggregates $(\mathbf{c}, \times 400), \mathrm{PAX} 2$ in structures of the renal vesicle $(\mathbf{d}, \times 400)$.
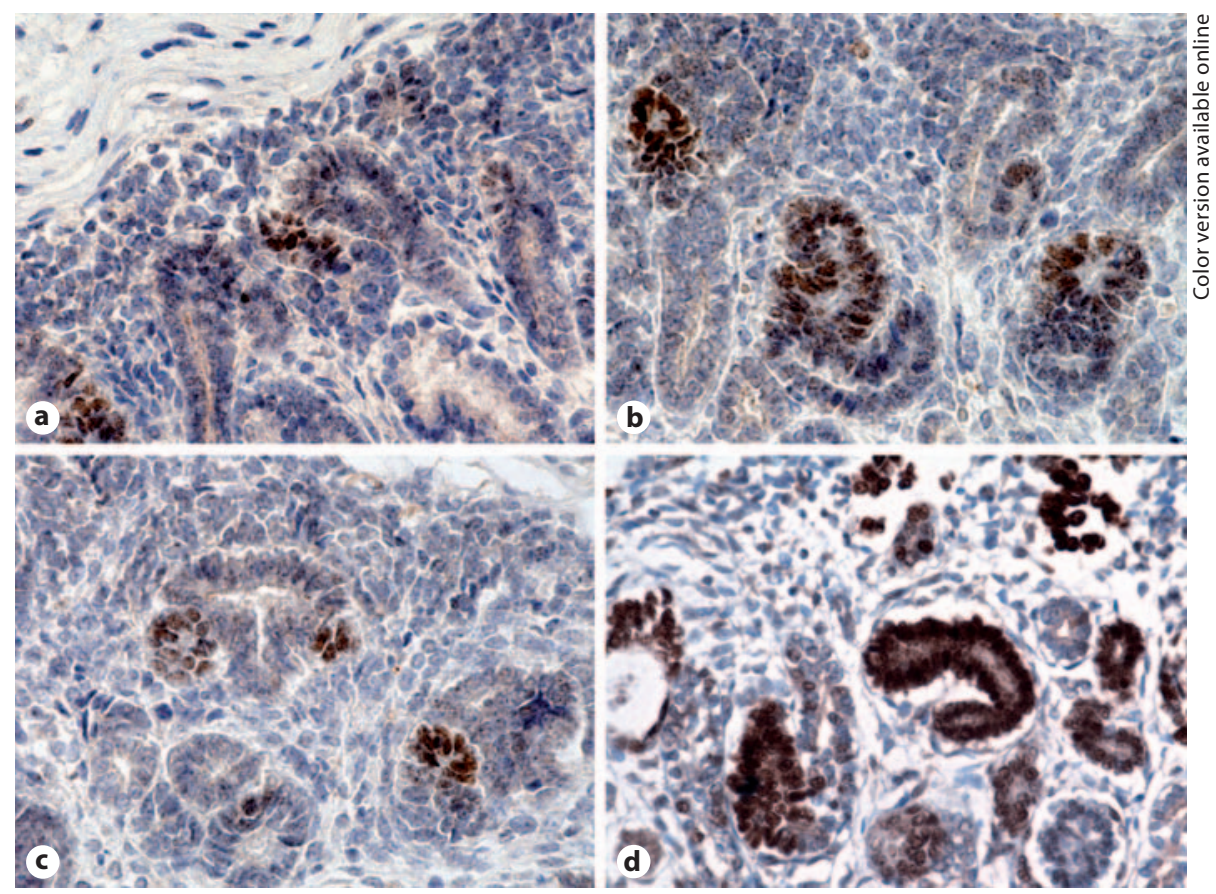

3 of them blastema and 1 also immature glomeruloid bodies.

Twenty of the nephroblastomas turned out to be entirely negative on whole sections of the tumours. Eight of the negative tumours were mixed nephroblastomas, 2 regressive ones, 2 stroma-type ones and 3 blastema-type nephroblastomas. All 4 epithelial-type nephroblastomas and also the cystic nephroblastoma revealed no expression of LIM1.

One regressive nephroblastoma showed diffuse positivity of tubular epithelial structures, but no staining in the blastemal areas was present. Interestingly, all other nephroblastomas were only positive in focal areas of the tumour. Two regressive nephroblastomas harboured focal positivity in tubular epithelial structures, 1 blastematype nephroblastoma also showed positivity in tubular areas. Eight mixed nephroblastomas demonstrated distinct nuclear positivity for LIM1, 4 of them in areas of tubular epithelial structures, 1 in blastemal areas, 2 in blastemal and epithelial areas, 1 of them including tubular structures and immature glomeruloid bodies. One mixed nephroblastoma turned out to be focally positive in tubular structures and the mesenchyme surrounding these structures as well as immature glomeruloid bodies.

In all nephroblastomas blastemal and epithelial structures were positive for PAX2. Additionally, 1 cystic nephroblastoma, 7 mixed nephroblastomas, 2 stroma- type nephroblastomas and 1 regressive nephroblastoma showed positivity of the undifferentiated mesenchyme. In 6 mixed nephroblastomas and 1 stroma-type nephroblastoma the expression of PAX2 in the mesenchyme was focally concentrated around tubular structures. In contrast, in the cystic and the regressive nephroblastoma as well as in 1 stroma-type and 1 mixed nephroblastoma, diffuse positivity for PAX2 was noted in the mesenchyme (also see table 3). The sample of a regressive nephroblastoma with diffuse positivity for LIM1 harboured distinct nuclear staining in the epithelial region, but negativity of the mesenchyme (fig. 2, also see table 3).

\section{Multicystic Dysplastic Kidneys}

Eleven samples of multicystic dysplastic kidneys were included in the study. The dysplastic areas ranged from focal replacement of kidney parenchyma to entire multicystic dysplastic kidneys. All samples were completely negative for LIM1 in the mesenchyme and in immature epithelial structures. All samples showed positivity for PAX2 in immature tubular structures, but no expression in the mesenchyme (fig. 3a-c).

\section{Renal Cell Carcinomas}

Twenty-nine cases of renal cell carcinomas were investigated in our study, including 19 clear cell carcinomas and 10 papillary renal cell carcinomas. All of the samples 
Fig. 2. Staining pattern of LIM1 and PAX2 in nephroblastomas. Distinct focal nuclear positivity of LIM1 can be seen in epithelial structures of a mixed nephroblastoma (a, $\times 400$ ), and a diffuse staining pattern in tubular structures of a regressive nephroblastoma $(\mathbf{b}, \times 200)$. The epithelial-predominant nephroblastomas show no expression of LIM1 (c, × 200). PAX2 expression is identified in blastema $(\mathbf{d}, \times 400)$, the epithelial component $(\mathbf{e}, \times 400)$ and small tubular structures $(\mathbf{f}, \times 400)$.
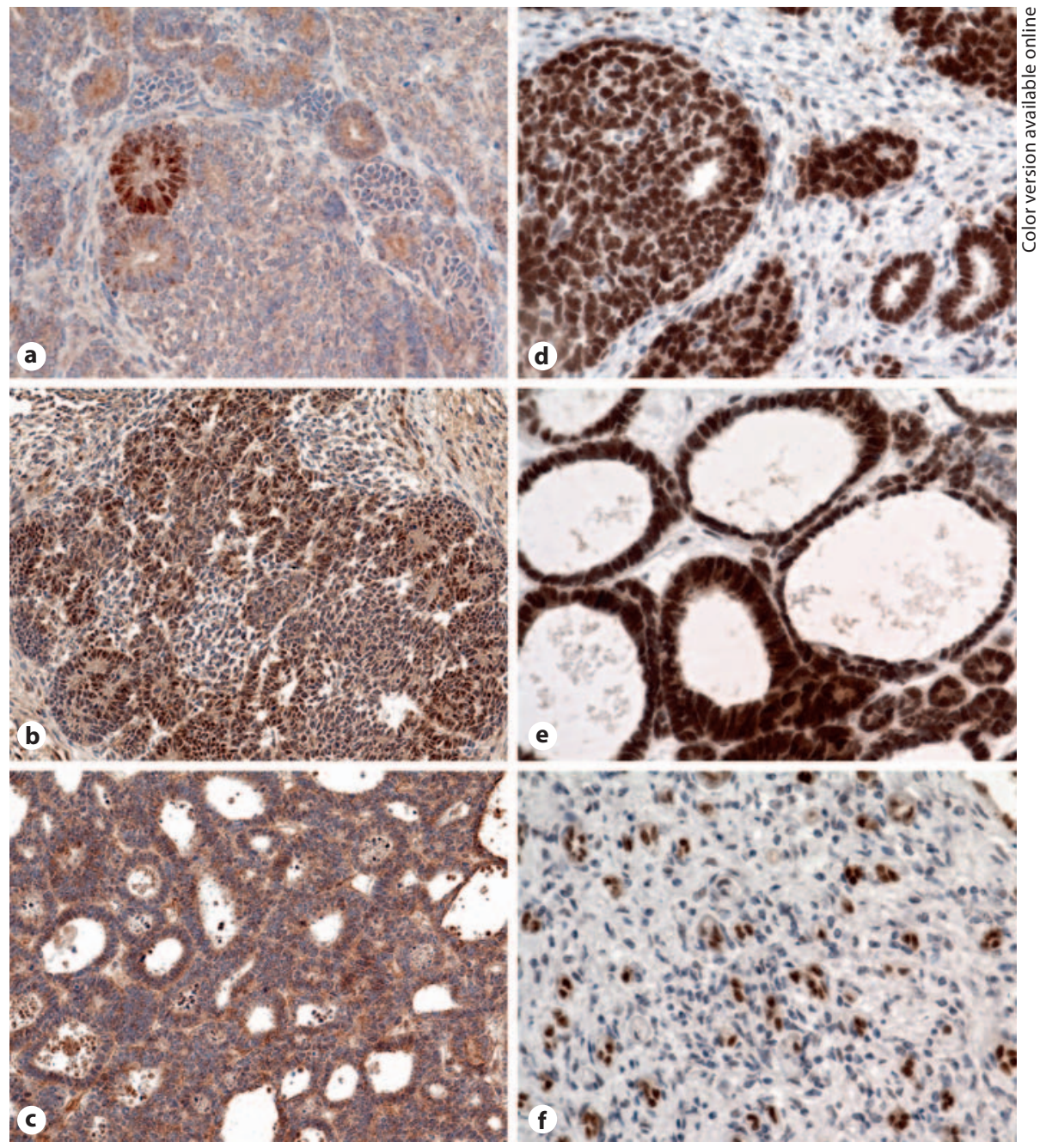

containing large areas of tumours had no detectable protein expression of LIM1 ascertained by complete negativity with immunostaining against LIM1. In contrast, all carcinomas showed distinct nuclear positivity for PAX2 (fig. 3d-g, also see table 3).

Additionally, QRT-PCR of 6 clear cell carcinomas and 2 papillary cell carcinomas was performed. Like mature kidney, none of the samples showed detectable levels of mRNA expression.

\section{LIM1 Overexpression in a Cell Line}

The MRC5 cell line not only features typical characteristics of fibroblasts but has already been successfully used in transduction and immortalisation studies [15]. Expression of LIM1 was not detected in this cell line. Overexpression of LIM1 in MRC5 cells induced a 3 times higher expression of KERATIN7 compared to cells over- expressing the control vector (fig. 4a). In contrast, a phenotypic alteration of the cells was not observed (fig. $4 b, c)$.

Cell cycle analysis was carried out in triplicates and showed one peak at G1 indicating diploidy. The percentage of cells within the phases of the cell cycle did not show a significant difference between cells overexpressing LIM1 and the control vector (fig. 4d, e).

\section{Discussion}

Regular nephrogenesis is the result of reciprocal interactions between the ureteric bud, the condensed metanephric mesenchyme surrounding the ureterical buds and the stromal mesenchyme. During this process the condensed metanephric mesenchyme differentiates into 
Fig. 3. LIM1 is completely absent in embryonal stroma and immature tubules of multicystic dysplastic kidney (a, b, ×400), renal clear cell carcinoma $(\mathbf{d}, \times 400)$ and renal papillary carcinoma $(\mathbf{e}, \times 400)$. Distinct expression of PAX2 can be seen in renal clear cell carcinomas $(\mathbf{f}, \times 400)$, renal papillary cell carcinomas $(\mathbf{g}, \times 400)$ and dysplastic tubular structures $(\mathbf{c}, \times 400)$.

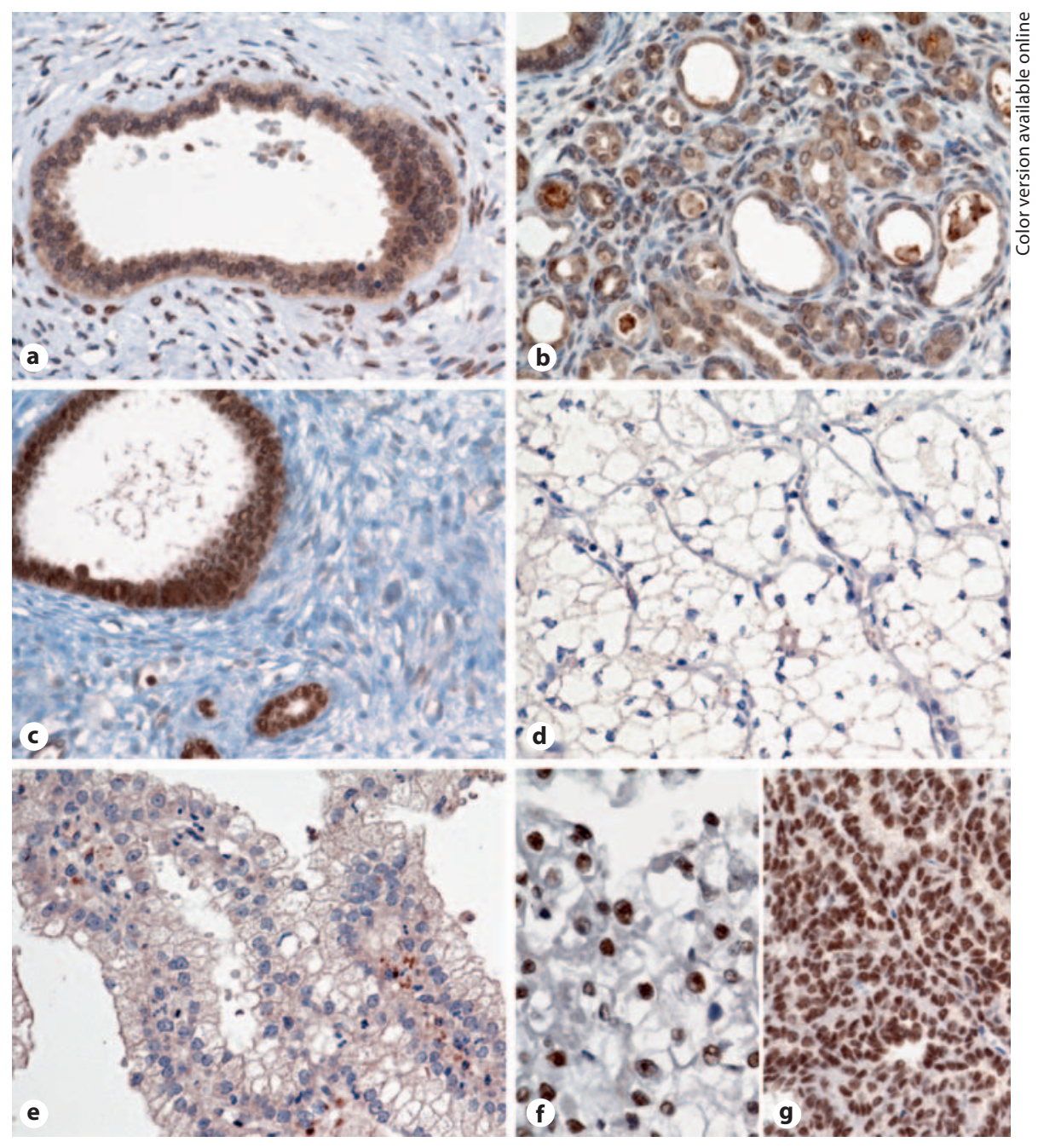

epithelial elements giving rise to mature nephrons [4, 16]. Mouse models have demonstrated an essential role of Lim1 during this process, as complete deficiency leads to renal agenesis $[9,10]$ and conditional knock-out in renal parenchyma to various renal malformations or diseases [11]. In our series of different stages of regular renal development we saw specific expression of LIM1 in structures derived from metanephric mesenchyme up to differentiation into immature glomerular structures between the gestational age of 10 and 30 weeks. No expression was detected in mature differentiated renal structures. These results parallel the role of $\operatorname{Lim} 1$ described during kidney development in mice and rats $[5,8]$. PAX2 is expressed in the condensing mesenchyme and structures of the renal vesicle, such as comma- and S-shaped bodies [17]. In our series expression of PAX2 was in accordance with previously published data. Interestingly, in one sample of 35 weeks of gestation, minimal residual undifferentiated tubuli showed a distinct expression of PAX2. A deficiency in normal human renal development and a disorder of metanephric differentiation results in renal dysplasia, which is characterized by disorganized renal parenchyma. Primitive ducts that can also become cystic are lined by undifferentiated epithelium and surrounded by undifferentiated mesenchyme. The morphological features described above can affect the whole kidney or only a part of the organ and represent a developmental abnormality with incomplete and abnormal differentiation [18]. In a high percentage of cases, an obstruction of the renal system can be identified. The reason for this obstruction, however, remains unexplained. It can be assumed, that the obstructive lesion and the malformed kidney result from changes in gene expression in the upper and lower urinary tract, as has already 
Table 3. Summary of results

\begin{tabular}{|c|c|c|}
\hline Sample & Lim1 expression & Pax2 expression \\
\hline $\begin{array}{l}\text { Developing kidneys } \\
7 \text { weeks of gestation }\end{array}$ & negative & not available \\
\hline $10-30$ weeks of gestation & $\begin{array}{l}\text { positivity of apical tips of comma- and } \\
\text { S-shaped bodies, pretubular aggregates, } \\
\text { immature glomeruli }\end{array}$ & $\begin{array}{l}\text { positivity of metanephric mesenchyme, comma- and } \\
\text { S-shaped bodies, pretubular aggregates, immature } \\
\text { glomeruli }\end{array}$ \\
\hline 35 weeks of gestation & negative & focal positivity of immature tubular structures \\
\hline $\begin{array}{l}40 \text { weeks of gestation } \\
2 \text { days } \\
2 \text { months }\end{array}$ & negative & negative \\
\hline $\begin{array}{l}\text { Nephroblastomas } \\
4 \text { epithelial-type } \\
\text { nephroblastomas }\end{array}$ & all negative & $\begin{array}{l}3 \text { positivity of epithelial structures; } 1 \text { positivity of } \\
\text { epithelial structures, mesenchyme negative }\end{array}$ \\
\hline $\begin{array}{l}2 \text { stroma-type } \\
\text { nephroblastomas }\end{array}$ & all negative & $\begin{array}{l}2 \text { positivity of tubular structures and mesenchyme } \\
\text { (1 diffuse and } 1 \text { focal) }\end{array}$ \\
\hline 16 mixed nephroblastomas & $\begin{array}{l}8 \text { negative; } 4 \text { focal positive in tubular } \\
\text { structures; } 1 \text { focal positive in blastema; } \\
1 \text { focal positive in blastema and tubular } \\
\text { structures; } 1 \text { focal positive in blastema } \\
\text { and tubular structures and glomeruloid } \\
\text { bodies; } 1 \text { focal positive in tubular } \\
\text { structures and surrounding mesenchyme } \\
\text { and glomeruloid bodies }\end{array}$ & $\begin{array}{l}5 \text { positivity of epithelial and blastemal structures, } \\
\text { focal positivity of mesenchyme; } 7 \text { positivity of } \\
\text { epithelial and blastemal structures, mesenchyme } \\
\text { negative; } 1 \text { positivity of epithelial structures, focal } \\
\text { positivity of mesenchyme; } 2 \text { positivity of epithelial } \\
\text { structures, mesenchyme negative; } 1 \text { positivity of } \\
\text { epithelial structures, diffuse positivity of mesenchyme }\end{array}$ \\
\hline 5 regressive nephroblastomas & $\begin{array}{l}1 \text { diffuse positivity of tubular structures; } \\
2 \text { negative; } 2 \text { focal positivity of tubular } \\
\text { structures }\end{array}$ & $\begin{array}{l}2 \text { positivity of epithelial structures, mesenchyme } \\
\text { negative; } 2 \text { positivity of epithelial and blastemal } \\
\text { structures, mesenchyme negative; } 1 \text { positivity of } \\
\text { epithelial structures, diffuse positivity of mesenchyme }\end{array}$ \\
\hline $\begin{array}{l}4 \text { blastema-type } \\
\text { nephroblastomas }\end{array}$ & $\begin{array}{l}3 \text { negative; } 1 \text { positive in tubular } \\
\text { structures }\end{array}$ & $\begin{array}{l}2 \text { positivity of blastemal structures; } 2 \text { positivity of } \\
\text { blastemal and tubular structures, mesenchyme negative }\end{array}$ \\
\hline 1 cystic nephroblastoma & negative & $\begin{array}{l}\text { positivity of epithelial structures, diffuse positivity of } \\
\text { mesenchyme }\end{array}$ \\
\hline $\begin{array}{l}\text { Multicystic dysplastic kidneys } \\
11 \text { samples of multicystic } \\
\text { dysplastic kidneys }\end{array}$ & negative & positive \\
\hline $\begin{array}{l}\text { Renal cell carcinomas } \\
19 \text { clear cell carcinomas }\end{array}$ & negative & positive \\
\hline $\begin{array}{l}10 \text { papillary renal cell } \\
\text { carcinomas }\end{array}$ & negative & positive \\
\hline
\end{tabular}

been described in some cases with a heterogeneous pattern of inheritance $[19,20]$. Genetic investigations of this entity have so far been sparse. Overexpression of $P A X 2$ and SALL1 (sal-like 1) and ectopic expression of BCL2 (B cell CLL lymphoma 2), GALECTIN3 and hepatocyte nuclear factor $1 \beta$ have been described [20-22]. A microarray analysis of this lesion showed no upregulation of
LIM1 [23], but in animal models deficiency of Lim1 expression leads to a diminished size of the kidneys and hydronephrotic changes, mimicking the human counterpart of this disease [5]. In one patient with MayerRokitansky-Kuster-Hauser syndrome showing bilateral multicystic dysplastic kidneys a microdeletion at chromosome 17q12 has been detected that includes among 

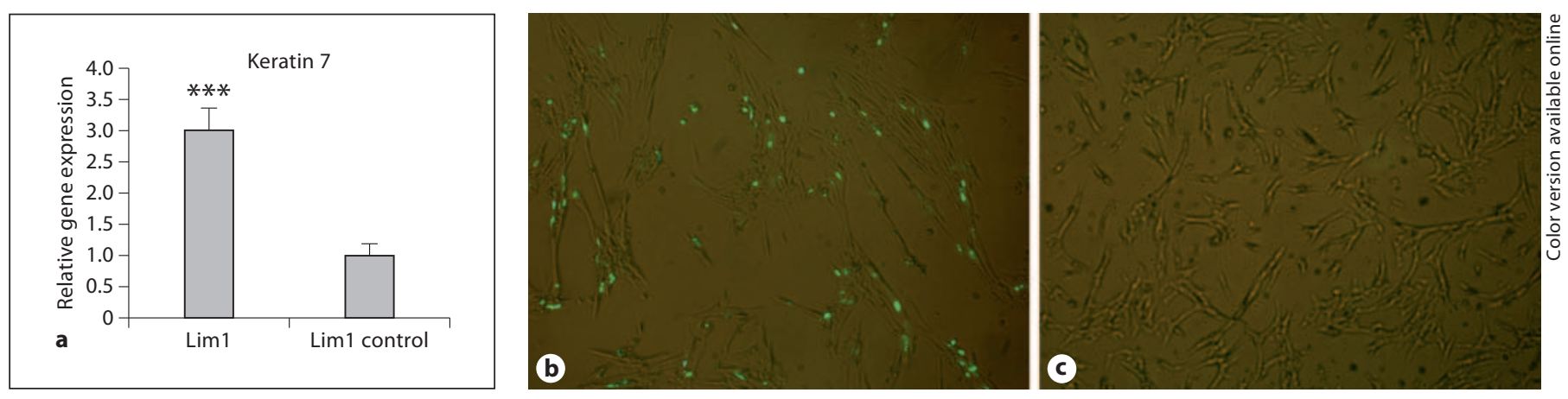

Fig. 4. Overexpression of LIM1 induces a statistically significant increase in KERATIN7 expression $\left({ }^{* * *} \mathrm{p}<0.001\right)$ in a mesenchymal cell line (a) but no phenotypic change (b) compared to control (c). No difference was detected in cell cycle analysis (d) in comparison to the control (e).
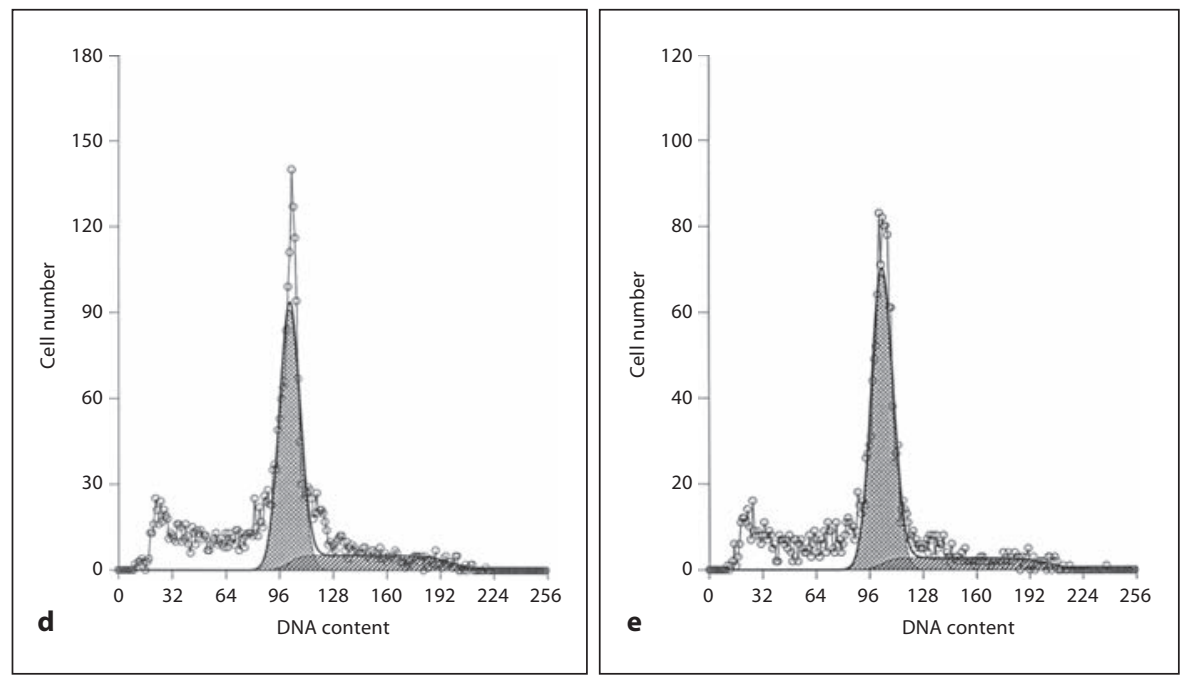

several genes also LIM1. However, a direct association of LIM1 deficiency and cystic kidneys could not be ascertained [24]. In our study we examined a series of multicystic dysplastic renal lesions ranging from focal disarrangement of the parenchyma to involvement of the whole kidney. None of the lesions investigated showed any expression of LIM1 despite the upregulation of PAX2, an upstream activator of LIM1 $[25,26]$. Our study therefore reinforces the concept that LIM1 deficiency might contribute to multicystic dysplastic kidneys.

Nephroblastomas are intriguing embryonal neoplasms resembling different stages of renal development, both morphologically and genetically. Several transcription factors that are active during renal development have also been found to be reactivated in nephroblastomas. These include HMGA2 (high mobility group AT-hook 2) [13], CITED1 [2] and PAX2 [3]. Despite the already described overexpression of PAX2 in nephroblastomas in blastema and some epithelial structures by in situ hybridization [3] and in the epithelial component by Western blot and immunohistochemistry [27], surprisingly the role of LIM1 in the pathogenesis of nephroblastomas has not been investigated in detail to date. Microarray analysis of a xenograft model of nephroblastomas [28] and an additional microarray analysis of various subtypes of primary nephroblastomas indicated that overexpression of LIM1 might play a role in their pathogenesis $[13,28]$. In our series of various subtypes of nephroblastomas only 1 of 12 samples with LIM1 expression showed diffuse staining in tubular structures. In all remaining samples, regardless of the morphological subtype, focal distinct nuclear positivity was detected, mostly in tubular structures but also in areas resembling immature metanephric mesenchyme and immature glomeruloid bodies. The expression of PAX 2 in our samples paralleled previous findings $[3,27]$; however, in some samples we were able to demonstrate expression of PAX2 in the mesenchymal component as well. In most samples PAX2 expression in mesenchyme was limited to focal areas, concentrating on mesenchymal layers around tubular structures. No obvious correlation could be identified between the expression patterns of LIM1 and PAX2. 
Additionally, we evaluated more common renal neoplasms, clear cell carcinomas and papillary cell carcinomas of the kidney, for expression of LIM1. LIM1 was neither detected on protein nor on mRNA levels. These results are in contrast to a recent study demonstrating positivity in 9 renal cell carcinomas by Western blot analysis [29]. According to the information provided by the vendor of this antibody, however, it may exhibit crossreactivity with other proteins in Western blot analysis. Interestingly, in our study all samples of renal cell carcinoma showed PAX2 expression, as already described for a majority in both tumour entities in different studies [30, 31]. These results and our findings indicate that PAX 2 is activated in renal cell carcinomas, but does not induce expression of downstream genes of this signalling pathway.

During renal development LIM1 plays a role in the induction of an epithelial cellular phenotype $[5,8]$. In our cell culture model of a mesenchymal cell line, overexpression of LIM1 led to an induction of expression of KERATIN7 indicating a transformation towards an epithelial phenotype, as KERATIN7 is typically expressed in simple epithelia, including the renal collecting ducts [32]. Overexpression of LIM1, however, was not suffi- cient to induce phenotypic changes in the cells. Cell cycle analysis of cell samples overexpressing LIM1 showed no increased progression of the cell cycle.

In conclusion, our study therefore strengthens the evidence for a causative role of LIM1 deficiency in the development of multicystic dysplastic kidney and the importance of LIM1 in mesenchymal-epithelial transition. Expression of LIM1 in most cases of nephroblastomas probably indicates a developmental phenomenon rather than an oncogenic activation, as has already been described for other transcription factors such as PTEN (phosphatase and tensin homolog on chromosome 10) [33]. This is also corroborated by the lack of LIM1 expression in various types of renal cell carcinomas. In a small subset of nephroblastomas with a more diffuse expression pattern, however, LIM1 might contribute to the pathogenesis of these lesions.

\section{Acknowlegdement}

This project was partly funded by the Jubiläumsfonds of the Österreichische Nationalbank (project No. 13646).

\section{References}

1 Parham DM, Qualman SJ, Teot L, Barr FG, Morotti R, Sorensen PH, Triche TJ, Meyer WH: Correlation between histology and PAX/FKHR fusion status in alveolar rhabdomyosarcoma: a report from the Children's Oncology Group. Am J Surg Pathol 2007;31: 895-901.

-2 Lovvorn HN, Westrup J, Opperman S, Boyle S, Shi G, Anderson J, Perlman EJ, Perantoni AO, Wills M, de Caestecker M: CITED1 expression in Wilms' tumor and embryonic kidney. Neoplasia 2007;9:589-600.

- 3 Eccles MR, Yun K, Reeve AE, Fidler AE: Comparative in situ hybridization analysis of PAX2, PAX8, and WT1 gene transcription in human fetal kidney and Wilms' tumors. Am J Pathol 1995;146:40-45.

-4 Dressler GR: The cellular basis of kidney development. Annu Rev Cell Dev Biol 2006;22: 509-529.

-5 Kobayashi A, Kwan KM, Carroll TJ, McMahon AP, Mendelsohn CL, Behringer RR: Distinct and sequential tissue specific activities of the LIM-class homeobox gene Lim1 for tubular morphogenesis during kidney development. Development 2005;132:2809-2823.
-6 Fujii TA, Kveta Cecklova, Gilbert DJ, Copeland NG, Jenkins NA, Westphal H: Genomic structure and chromosomal location of the murine LIM class homeobox gene Lhx1. Mamm Genome 1998;9:81-83.

7 Phillips JC: Assignment of LHX1 to human chromosome bands $17 \mathrm{q} 11.2 \rightarrow \mathrm{q} 12$ by use of radiation hybrid mapping and somatic cell hybridization. Cytogenet Genome Res 2002; 97:140D

8 Karavanov AA, Karavanova I, Peratoni A Dawid IB: Expression pattern of the rat Lim1 homeobox gene suggests a dual role during kidney development. Int J Dev Biol 1998;42: 61-66.

-9 Shawlot W, Behringer RR: Requirement for Lim1 in head-organizer function. Nature 1995;374:425-430.

-10 Kobayashi A, Shawlot W, Kania A Behringer RR: Requirement of Lim1 for female reproductive tract development. Development 2004;131:539-549.

11 Pedersen A, Skjong C, Shawlot W: Lim1 is required for nephric duct extension and ureteric bud morphogenesis. Dev Biol 2005;288: 571-581.
12 Hunter CS, Rhodes SJ: Lim-homeodomain genes in mammalian development and human disease. Mol Biol Rep 2005;32:67-77.

-13 Sredni ST, Gadd S, Huang CC, Breslow N, Grundy P, Green DM, Dome JS, Shamberger RC, Beckwith JB, Perlman EJ: Subsets of very low risk Wilms tumor show distinctive gene expression, histologic and clinical features. Clin Cancer Res 2009;15:6800-6809.

14 Guertl B, Ratschek M, Harms D, Jaenig U, Leuschner I, Poremba C, Hoefler G Clonality and loss of heterozygosity of WT genes are early events in the pathogenesis of nephroblastomas. Hum Pathol 2003;34:278281

15 Taylor LM, James A, Schuller CE, Brce J, Lock RB, Mackenzie KL: Inactivation of p16INK4a, with retention of $\mathrm{pRB}$ and $\mathrm{p} 53 /$ p21cip1 function, in human MRC5 fibroblasts that overcome a telomere-independent crisis during immortalization. J Biol Chem 2004;279:43634-43645.

16 Saxen L, Sariola H: Early organogenesis of the kidney. Pediatr Nephrol 1987;1:385-392.

17 Dressler GR, Woolf AS: Pax2 in kidney development and renal disease. Int J Dev Biol 1999;43:463-468. 
18 Bernstein J, Risdon RA: Kidneys and urinary tract; in Gilbert-Barness E (ed): Potter's Pathology of the Fetus and Infant, ed 1. St. Louis, Mosby, 1997, vol 2, pp 875-879.

19 Woolf AS: The life of the human kidney before birth: its secret unfolds. Pediatr Res 2001;49:8-10

-20 Winyard PJD, Risdon RA, Sams VR, Dressler GR, Woolf AS: The PAX2 transcriptionfactor is expressed in cystic and hyperproliferative dysplastic epithelia in human kidney malformations. J Clin Invest 1996;98:451459.

21 Woolf AS, Winyard PJ: Gene expression and cell turnover in human renal dysplasia. Histol Histopathol 2000;15:159-166.

-22 Ulinski T, Lescure S, Beaufils S, Guigonis V Decramer S, Morin D, Clauin S, Deschenes B, Bouissou F, Bensman A, Bellanne-Chantelot C: Renal phenotypes related to hepatocate nuclear factor- $1 \beta$ (TCF2) mutations in a pediatric cohort. J Am Soc Nephrol 2006;17: 497-503.

-23 Jain S, Suarez AA, McGuire J, Liapis H: Expression profiles of congenital renal dysplasia reveal new insights into renal development and disease. Pediatr Nephrol 2007;22: 962-974.
24 Bernadini L, Gimelli S, Gervasini C, Carella M, Baban A, Frontino G, Barbano G, Divizia MT, Fedele L, Novelli A, Béna F, Lalatta F, Miozzo M, Dallapiccola B: Recurrent microdeletion at 17q12 as a cause of Mayer-Rokitansky-Kuster-Hauser (MRKH) syndrome: two case reports. Orphanet J Rare Dis 2009; $4: 25$

25 Reidy KJ, Rosenblum ND: Cell and molecular biology of kidney development. Semin Nephrol 2009;29:321-337.

26 Narlis M, Grote D, Gaitan Y, Boualia SK, Bouchard $M$ : Pax2 and Pax8 regulate branching morphogenesis and nephron differentiation in the developing kidney. J Am Soc Nephrol 2007;18:1121-1129.

27 Dressler GR, Douglass EC: Pax-2 is a DNAbinding protein expression in embryonic kidney and Wilms tumor. Proc Natl Acad Sci USA 1992;89:1179-1183.

28 Dekel B, Metsuyanim S, Schmidt-Ott KM, Fridman E, Jacob-Hirsch J, Simon A, Pinthus J, Mor Y, Barasch J, Amariglio N, Reisner Y, Kaminski N, Rechavi G: Multiple imprinted and stemness genes provide a link between normal and tumor progenitor cells of the developing human kidney. Cancer Res 2006;66:6040-6049.
29 Dormoy V, Danilin S, Lindner V, Thomas L, Rothhut S, Coquard C, Helwig JJ, Jacqmin D, Lang H, Massfelder T: The sonic hedgehog signalling pathway is reactivated in human renal cell carcinoma and plays orchestral role in tumor growth. Mol Cancer 2009;8: 123.

30 Oczan A, Zhai Q, Javed R, Shen SS, Coffey D, Krishnan B, Truong LD: PAX-2 is a helpful marker for diagnosing metastatic renal cell carcinoma. Arch Pathol Lab Med 2010;134: 1121-1129.

31 Memeo L, Jhang J, Assaad AM, McKiernan JM, Murty VVVS, Hibsoosh H, Tong GX, Manuskhani MM: Immunohistochemical analysis for cytokeratin 7, KIT and PAX2. Am J Clin Pathol 2007;127:225-229.

32 Chu PG, Weiss LM: Keratin expression in human tissues and neoplasms. Histopathology 2002;40:403-439.

33 Grill C, Guelly C, Ebner B, Leuschner I, Hauser-Kronberger C, Hoefler G, Guertl B: Loss of PTEN/MMAC1 activity is a rare and late event in the pathogenesis of nephroblastomas. Hum Pathol 2010;41:1172-1177. 